\title{
Tarihi Hundi Hatun (Kunç) Köprüsünün Artan Trafik Yükü Altında Davranışının İncelenmesi
}

\section{Investigation of Behaviour of Historical Hundi Hatun (Kunç) Bridge Under Increasing Traffic Load}

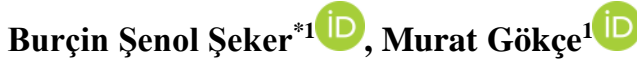 \\ ${ }^{1}$ Amasya Üniversitesi Mimarlik Fakültesi, 05200 Amasya, TÜRKIYE
}

Başvuru/Received: 10/11/2020

Kabul / Accepted: 19/03/2021

Çevrimiçi Basım / Published Online: 23/05/2021

Son Versiyon/Final Version: 18/06/2021

\section{$\ddot{O} z$}

Amasya kentinde yer alan Hundi Hatun (Kunç) köprüsünün artan trafik yükleri etkisi altındaki davranışı bu çalışmada detaylı olarak incelenmiştir. Köprü, halihazırda taşıt trafiğine açık durumda olup, şehrin en işlek mevkilerinden birinde bulunmaktadır. Bundan dolayı köprü, oldukça fazla trafik yüküne maruz kalmaktadır. Yakın zamanda şehir içinde açılan tünelden hasıl olan trafik yükü de köprüye doğru iletilmekte ve köprünün her iki yakasında trafik sıkışıklığına neden olarak, köprü üzerinde uzun süre araç beklemesine neden olmaktadır. Bu yükün köprü üzerinde meydana getirdiği olumsuz durum bu çalışmada, farklı araç yükleri dikkate alınarak incelenmiştir. Malzeme modeli olarak Mohr-Coulomb malzeme modeli kullanılmıştır. Köprü üzerinde mevcut olan her iki şeritin en olumsuz durum olan tamamen dolu olmasını durumuna göre analizler gerçekleştirilmiş̧ir. Araç yükü olarak otomobil, minibüs, kamyonet ve otobüs yükleri dikkate alınmış ve meydana gelen gerilme ve deformasyonlar belirlenmiştir. Ayrıca meydana gelen deformasyonların sınır değeri aşmadığı, oluşan çekme gerilmelerinin basık kemer mesnet ve tepe noktalarında, ayrıca köprü taşıyıcı kemerleri üst kısmındaki yan duvarlarda yoğunlaştığı tespit edilmiştir. Bunlara ek olarak rijit blok analizi yöntemini kullanan Limitstate: Ring yazılımı ile de analizler gerçekleştirilmiş ve yenilme mekanizmaları ve buna sebep olan minimum dingil yükleri de tespit edilmiştir. Çalışmadan elde edilen bulguların ilerdeki restorasyon çalışmaları için yol gösterici olması hedeflenmiştir.

\section{Anahtar Kelimeler}

"Hundi hatun (kunç) köprüsü, artan trafik yükü, mohr coulomb malzeme modeli, amasya"

\begin{abstract}
The behavior of Hundi Hatun (Kunç) Bridge located in Amasya city under the effect of increasing traffic loads has been examined detailed in this study. The bridge is currently open to vehicle traffic and is located in one of the busiest locations in the city. Therefore, the bridge is exposed to a huge traffic load. The traffic load resulting from the tunnel opened in the city recently is transferred towards the bridge and causes traffic congestion on both sides of the bridge, causing the vehicle to wait on the bridge for a long time. The negative situation caused by this load on the bridge has been examined in this study, considering different vehicle loads. Mohr-Coulomb material model is used as the material model. Analyzes have been carried out according to the most unfavorable situation that both lanes on the bridge is full. Automobile, minibus, van and bus loads were taken into consideration as vehicle load and the resulting stress and deformations were determined. In addition, it has been determined that the deformations that occur do not exceed the limit value, maximum tensile stresses are concentrated on the flattened arch support and around key stone points, and also on the side walls of the upper part of the arches. In addition to these, analyzes were carried out with the Limitstate: Ring software, which uses the rigid block analysis method, and the failure mechanisms and the minimum axle loads that cause failure were determined. The findings obtained from the study are aimed to be a guide for future restoration studies.
\end{abstract}

Key Words

"Hundi hatun (kunç) bridge, increasing traffic load, mohr - coulomb material model, amasya" 


\section{Giriş}

Tarihi doku, geçmişten günümüze ulaşmış yerleşimleri ve eserleri kapsamaktadır. Büyük bir özenle inşa edilmiş olan bu tarihi eserler, içerdikleri farklı üsluplar ve biçimler ile tarihi dokuyu oluşturmaktadırlar. Böylece meydana gelen kültürel miraslar, toplumların kimliğinin ve sürekliliğinin sembolü olmaktadırlar. Hatta bu miras; tarihsellik yanında, sanatsal, sosyal, ekonomik, dini, hatta politik birçok değeri de içermektedir. Bu sebeple bu eserlerin, özgün halleriyle koruyup gelecek nesillere aktarılması toplumsal bir zorunluluktur. Türkiye coğrafyası, farklı kültürleri bir arada barındırmaktadır. Bu durumda, bu eserlerin gelecek nesillere aktarılmasında bu bölge insanına dünya çapında bir sorumluluk yüklemektedir. Bu yapıların korunması ile, ekonomik ve tarihsel süreklilik sağlanmış olacaktır (Meriç et. al. (2019)). Bu açıdan bakıldığında, tarihi dokuyu oluşturan bütün bu eserlerin zamanla bozulmalarının ve yıkılmalarının önüne geçilmesi çok önem arz etmektedir.

Literatürde, tarihi yığma köprüleri ile ilgili yapılmış farklı çalı̧̧malar mevcuttur. (Conde et.al. 2016) yaptıkları çalışmada, tarihi bir köprünün çökme yüküne, dolgu malzemesinin ve kemerlerin geometrisinin etkilerini araştırmışlardır. Limit analiz yöntemi ile, geometrik nonlineer etkilerde analizlerde gözönüne alınmıştır. Tarihi köprülerin sismik değerlendirilmelerinin ve performanslarının belirlendiği yayınlarda literatürde mevcuttur (Karaton et. al. (2009)). Tubaldi et al. (2020) çok açıklıklı yığma köprü üzerinde geometrik ve mekanik özelliklerin köprü davranışına etkisini, köprü geometrisinin parametrik olarak değişimini ve köprü ayaklarının çökmesini de analize katarak araştırmışlardır. (Kamiński, 2018), yığma köprüler üzerinde nihai sınır durum analizi ile sınır durum analiz yöntemlerini uygulamıştır. Çalışmada yöntemler tanıtılmış, yığma köprüler üzerindeki potansiyelleri ve etkileri tartışılmıştır. (Pepi et al. (2017) yaptıkları çalışmada, ağır hasarlı bir köprü üzerine geometrik araştırmalar, dinamik testler gerçekleştirmişler, köprünün sayısal modelini oluşturarak, köprünün yapısal performansını değerlendirmişlerdir. Tarihi yığma köprülerin rehabilitasyonunu ve renovasyonunu inceleyen araştırmalar (Paeglitis et. al. (2013); Rodrigo et. al. (2015); Rodrigues et. al. (2008) literatürde mevcut olduğu gibi, probabilistik güvenliğini inceleyen tarzda çalışma (Pouraminian et al. (2020) da bulunmaktadır. Yığma köprüler üzerinde farklı türde yapılan araştırmalar da literatürde mevcuttur (Ataei et.al. (2017); Augusthus et.al. (2020); Hokelekli et.al. (2019); Kindij et.al.(2013); Rahman et.al. (2010), Onat ve Yön (2018), Özmen ve Sayın (2018), Kolla et.al. (2021) ve Nobile ve Bartolomeo (2015). Anadolu'da tarih öncesinden günümüze kadar birçok toplum tarafindan, ulaşım problem ve ihtiyaçlarının çözülebilmesi amacıyla bazı yapılar inşa edilmiştir. Bu problemlerden belki de en büyüğü olarak gördükleri, büyük açıklıklı nehirlerin ve vadilerin geçilebilmesi için ise, kemer köprüler yapılmış ve o zamanki koşullara göre dizayn edilmişlerdir. Anadolu tarihinde kemer köprüler fazla sayıda inşa edilmişlerdir. Tarihi kemerli köprülere özellikle Osmanlı ve Selçuklu İmparatorluğu döneminde çokça rastlanılmaktadır. Anadolu'da bulunan tarihi kemerli köprülerin birçoğu zaman içerisinde depremlere, yangınlara maruz kalmıştır. Ayrıca, coğrafi konumları itibariyle savaşlardan da ciddi oranda etkilenmişler ve zarar görmüşlerdir. Meydana gelen bu zararlar kimi zaman onarılabilir ölçülerde kalsa da kimi zaman köprülerin yıkılmasına neden olmuşlardır. Medeniyetin beşiği olan Anadolu'da, geçmişten günümüze miras kalan bu köprüler hem kırsal hem de kentsel alanlarda, ülke ulaşım ağının bir parçası konumunda hala hizmet vermektedirler. Bunların yanı sıra, inşa edilirken kullanılan yapı malzemelerin ömürlerini tamamlaması veya tasarlandıkları dönemde dikkate alınan hizmet yükleri ile günümüzde teknolojinin gelişimi ile meydana gelen yükler arasındaki belirgin farklar bu köprülerin zarar görmesine ya da tamamen kullanılamaz hale gelmesine sebep olabilmektedir. Ancak günümüz koşullarındaki araçların kapasiteleri, yoğunlukları ve tonajları, bu köprülerin günümüz koşullarında tekrar değerlendirilmesini zorunlu kılmaktadır (Kaya, 2018).

Bu çalışmada da Amasya ilinde bulunan tarihi Hundi hatun köprüsünün artan araç yükü altında analizi yapılmış, taşıma kapasitesi ile yapıda oluşabilecek olası hasar durumları araştırılmıştır.

\section{Hundi Hatun (Kunç) Köprüsü Tarihi ve Mimari Özellikleri}

Amasya'da, (Şekil 1) güneybatı-kuzeydoğu yönünde akan Yeşilırmak, kenti iki bölgeye ayırmaktadır. Bu nedenle, bu iki ayrı kesimin birbirine bağlantısının sağlanabilmesi için, tarih boyunca nehir üzerinde muhtelif yerlere köprüler inşa edilmiştir. Bu köprülerden biri olan Hundi Hatun Köprüsü, şehrin doğusunda, Yeşilırmak üzerinde bulunmaktadır. Güneyinde Bayezid Paşa Camii, kuzey tarafında Büyük Ağa medresesi bulunmaktadır. Sultan Mesut'un kızı, Hundi Hatun tarafından inşa ettirilmiştir. 1900 ve 1959 yıllarında onarım görmüştür. 4 gözlü, basık yuvarlak kemerlidir. Boyu $67 \mathrm{~m}$, eni $8 \mathrm{~m}$ ve yüksekliği 10,50 m dir (Çulpan, 2002). Köprü genel görünümü Şekil 2 de verilmektedir. 


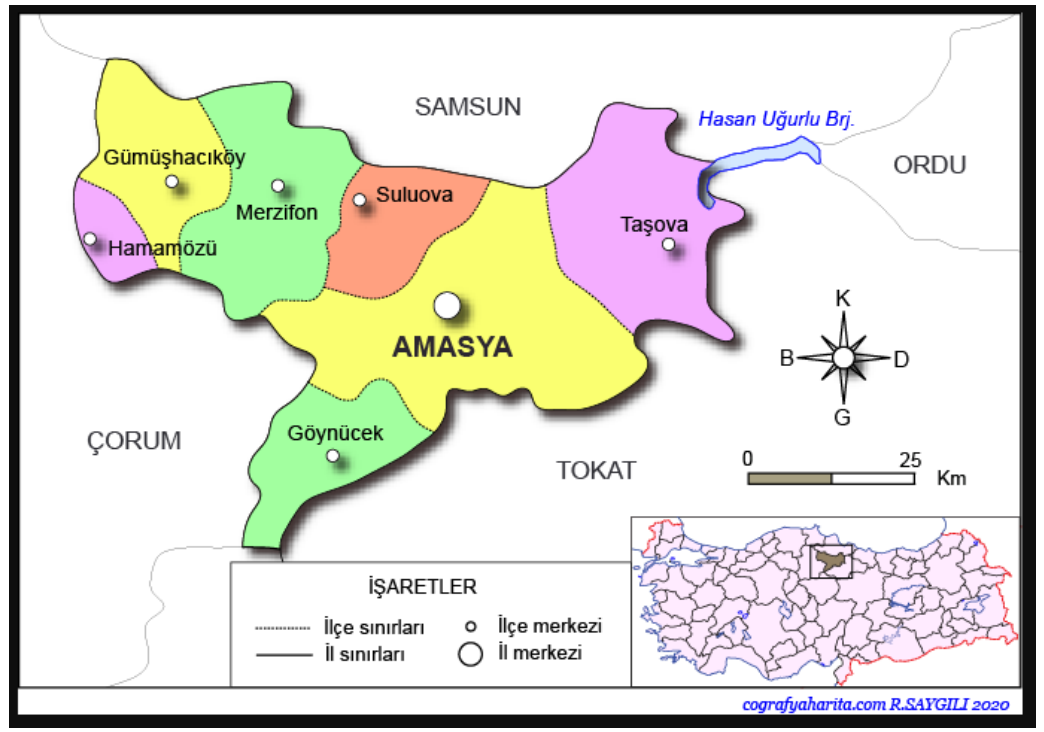

Şekil 1. Türkiye Haritası ve Amasya Şehir Konumu (http://cografyaharita.com/haritalarim/41_amasya_ili_haritasi.png)
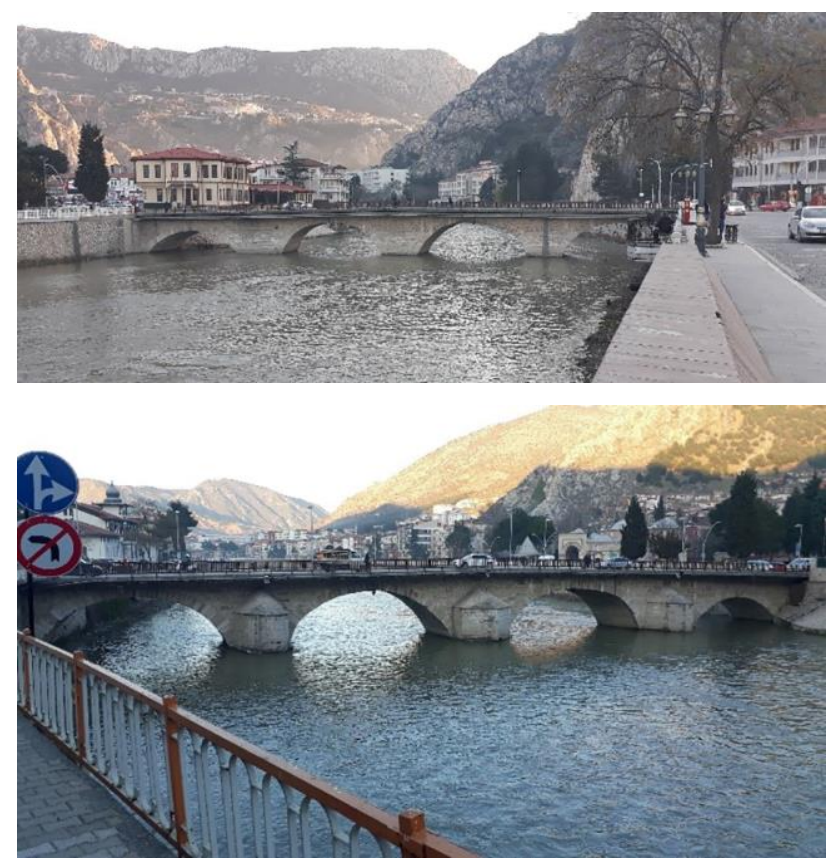

Şekil 2. Hundi Hatun (Kunç) Köprüsü Mansap ve Memba Görünümleri

\section{Hundi Hatun Köprüsü Sonlu Elemanlar Modeli ve Malzeme Özellikleri}

\subsection{Sonlu Elemanlar Modeli}

Tarihi eserler farklı malzemelerin karışımı ile inşa edilmiş yapı türleridir. Yapının bazı bölgeleri taş, diğer kısımları tuğ ladan olabilmektedir. Genellikle bağlayıcı malzeme de harç olmaktadır. Bütün bu fraklı malzeme türlerinin sonlu elemanlar ortamında modellenebilmesi için mikro, basitleştirilmiş mikro ve makro modelleme teknikleri kullanılmaktadır. Makro modelleme tekniğinde, taş ve harç elemanları homojenleştirilmiş bir halde tek malzeme özelliği olarak ele alınmaktadır (Karaton, 2017). Bu çalışmada, makro modelleme tekniği kullanılarak analizler gerçekleştirilmiştir.

\subsection{Malzeme Özellikleri}

Çalışma kapsamındaki tarihi köprüde kullanılan ana malzeme, köprü kemerleri ve yan duvarları için kumtaşıdır. İç kısımda ise dolgu malzemesi bulunmaktadır. Köprüde kullanılan malzeme mekanik özellikleri, aynı şehirde bulunan bir diğer tarihi köprü üzerinde yapılan laboratuvar deney sonuçları alınarak belirlenmiş̧ir. Bu deney sonuçlarına göre, taş malzeme için ortalama basınç dayanımı 41,46 MPa, birim hacim ağırlığı ise $2646 \mathrm{~kg} / \mathrm{m}^{3}$ olarak tespit edilmiştir (Çakır et. al., 2015). Harç için ise, basınç dayanımı $6 \mathrm{MPa}$ 
olarak alınmıştır (Altaş et. al. 2012). İç kısımdaki dolgu malzeme için ise, elastisite modülü $\mathrm{E}=500 \mathrm{MPa}$, birim hacim ağırlığı 1800 $\mathrm{kg} / \mathrm{m}^{3}$ olarak alınmıştır (Karaton, 2017). Duvar çekme dayanımı, basınç dayanımının \%10 u olarak alınmıştır. Bu bilgilere göre belirlenen (Türkiye Bina Deprem Yönetmeliği, 2019), malzeme mekanik özellikleri Tablo 1 de gösterilmiştir.

Tablo 1. Köprüde Kullanılan Homojenleştirilmiş Malzemelerin Fiziksel ve Mekanik Özellikleri

\begin{tabular}{llllll}
\hline $\begin{array}{l}\text { Köprï } \\
\text { bölümüi }\end{array}$ & $\begin{array}{l}\text { Elastisite } \\
\text { modülüi } \\
(\mathbf{M P a})\end{array}$ & $\begin{array}{l}\text { Poisson } \\
\text { oranı }\end{array}$ & $\begin{array}{l}\text { Birim hacim } \\
\text { ağırlığı } \\
\left(\mathbf{N} / \mathbf{m}^{3}\right)\end{array}$ & $\begin{array}{l}\text { Ortalama } \\
\text { basıç } \\
\text { dayanımı } \\
(\mathbf{M P a})\end{array}$ & $\begin{array}{l}\text { Ortalama } \\
\text { çekme } \\
\text { dayanımı } \\
(\mathbf{M P a})\end{array}$ \\
\hline $\begin{array}{l}\text { Kemerler ve } \\
\text { yan duvarlar }\end{array}$ & 8110 & 0,2 & 26460 & 8,11 & 0,811 \\
\hline
\end{tabular}

\section{Yapısal Analizler}

Oldukça kompleks geometriye ve malzeme özelliğine sahip olan tarihi yapıların incelenmesinde sonlu elemanlar yöntemi ile çözüm yapan programlar günümüzde geniş çaplı olarak kullanım alanı bulmaktadırlar. Bu programlar sayesinde, tarihi yapıların statik ve dinamik yükler altında genel davranışı ve kritik bölgeleri tespit edilebilmektedir. Bu çalışmada oluşturulan köprü üç boyutlu modeli, ANSYS (ANSYS, 2019) ortamında lineer ve lineer olmayan analizlere tabi tutulmuştur. Lineer analizler için, her düğüm noktasında üç serbestlik derecesine sahip olan Solid 186 eleman tipi kullanılmıştır. Sayısal model toplamda 5224 eleman ve 24621 düğüm noktasından oluşmaktadır. Tarihi köprünün sonlu eleman modeli Şekil 1 de görülmektedir.

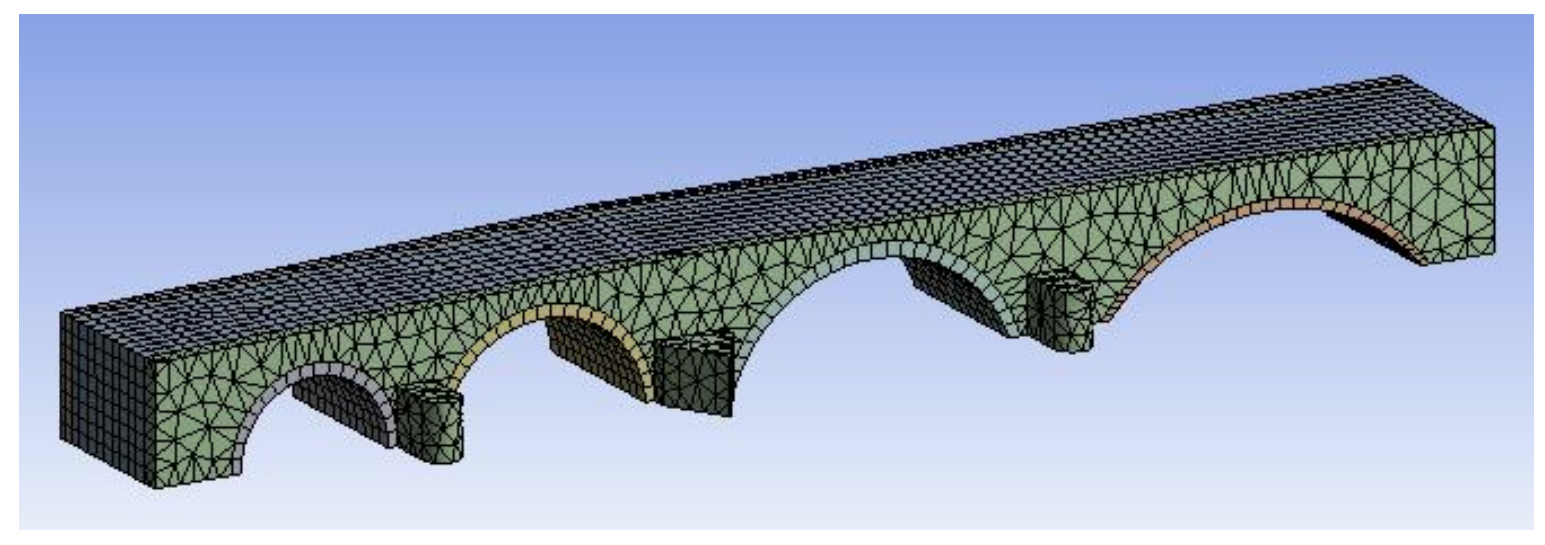

Şekil 3. Hundi Hatun Köprüsü Sonlu Eleman Modeli

Sayısal analizler için makro modelleme tekniği kullanılmışıı. Bu teknikte, yapıyı oluşturan birim elemanları ve harç birlikte tek bir malzeme olarak düşünülmekte ve bu yeni elemana birimlerin dayanımına bağlı olarak malzeme özellikleri atanmaktadır. Sonlu elemanlar yöntemini kullanan bilgisayar programları için analiz süresini kısalttığından dolayı tercih edilen bir yöntemdir (Karaton, 2017). Bu çalışmada, makro modelleme tekniği kullanılarak analizler gerçekleştirilmiştir.

Lineer analizler için, Tablo 1 de verilen malzeme özellikleri oluşturulan sonlu eleman modelinin ilgili yerlerine atanmıştır. Lineer olmayan analizlerde ise, tarihi eserlerde literatürdeki çalışmalarda (Karaton, 2017) yer bulan Mohr- Coulomb malzeme modeli taş ve dolgu malzeme için kullanılmıştır. Bu modelde yenilme yüzeyi formülasyonu;

$$
\tau=c+\sigma \tan \phi
$$

olarak ifade edilmekte, $c$ ve $\phi$ parametreleri bilindiğinde yenilme yüzeyi tanımlanmış olmaktadır (https://en.wikipedia.org/wiki/Mohr\%E2\%80\%93Coulomb_theory). Bu çalışmada taş ve dolgu kısımları için ele alınan $c$ ve $\phi$ parametreleri Tablo 2 de verilmektedir. 
Tablo 2. Köprüde kullanılan homojenleştirilmiş malzemelerin Mohr- Coulomb Malzeme modeli özellikleri (Tiberti, 2018 ve Karaton, 2017)

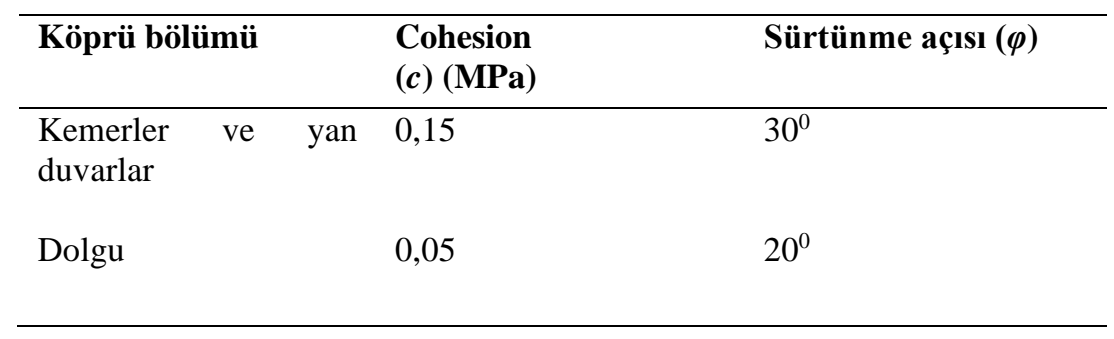

Çalışmada ele alınan tarihi Hundi Hatun köprüsü, şehir içerisinde yoğun bir trafik yüküne maruz kalmaktadır. Yakınlarda hizmete giren tünelin yoğun trafiğinin de bu bölgeye verilmesi neticesinde, köprünün iki ucunda trafik sıkışması meydana gelmekte ve köprüden geçiş yapan araçlar köprü üzerinde beklemek zorunda kalmaktadırlar. Bu durumda, köprüye büyük miktarda araç yükünün etkimesi durumu ortaya çıkmaktadır. Şekil 4 de, bu durum görülmektedir.

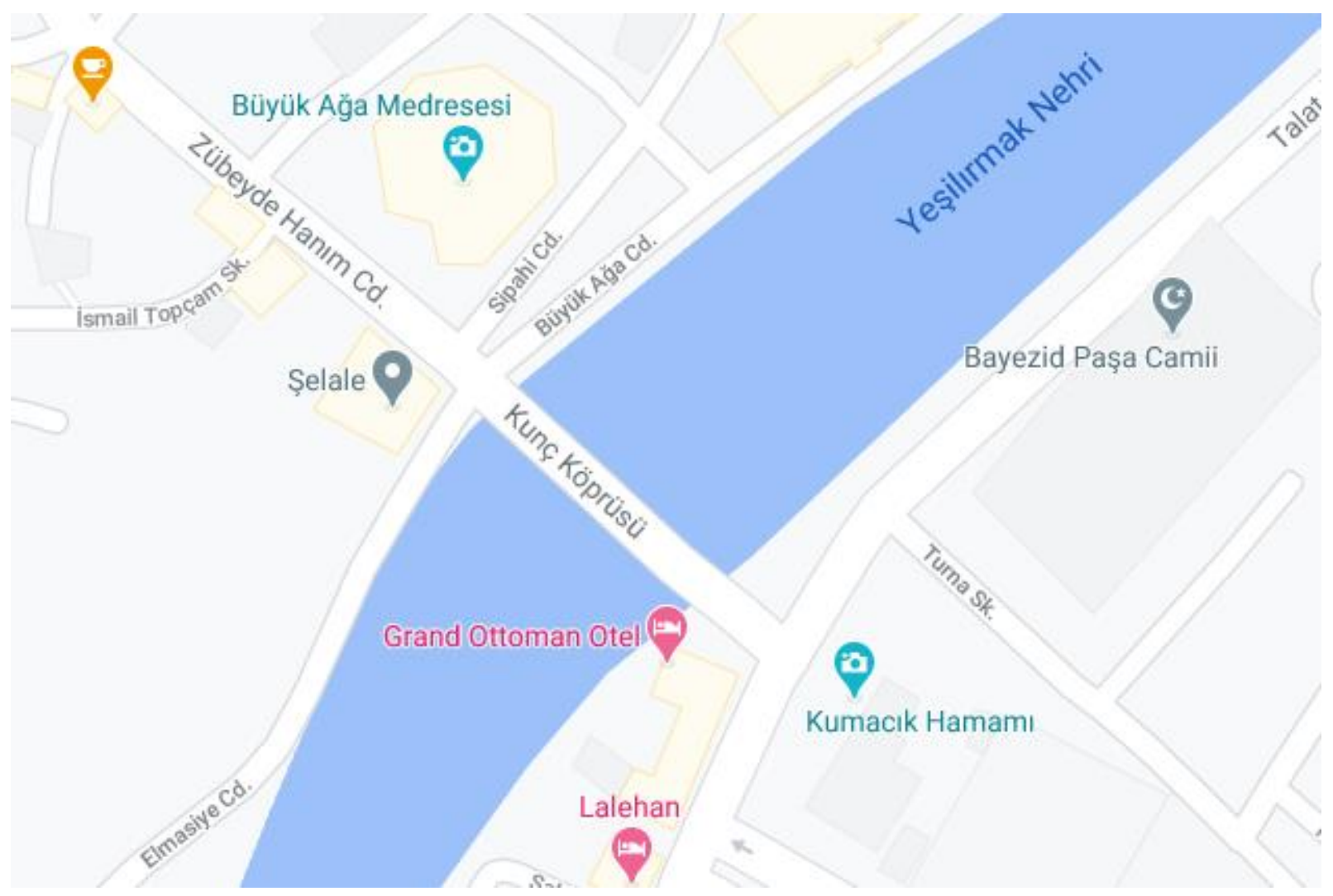

Şekil 4. Hundi Hatun Köprüsü Şehiriçi Konumu ve Üzerindeki Yoğun Trafik Yükü (https://www.google.com/maps/@40.6579007,35.8350253,17.79z?hl=tr)

Bu çalışmada, köprüye gelen bu yüklerin etkisinde köprüde meydana gelen gerilme ve deformasyon değerlerinin tespit edilebilmesi için, köprüye etkitilecek farklı araç dingil ve toplam yükleri Tablo 3 de verilmektedir. Bu araç yükleri köprü üzerine 1 metre aralıklı olarak etkitilmiştir. Yüklemelerde en olumsuz durumları ele alarak, köprüye en büyük yük değerleri yüklenmiştir. Bu durumun oluşabilmesi için, köprünün her iki şeridinin Tablo 3 de verilen ve detaylı dingil ağırlıkları verilen araçlarla yüklendiği durumlar gözönüne alınmıştır. Böylece, maksimum gerilme ve deformasyonların oluşması amaçlanmıştır. Bu araç yükleri köprü üzerine etkitilirken, araçların dingil mesafeleri de dikkate alınmış ve dingil yükleri her bir tekere eşit dağıtılarak gerçek yükleme durumu köprü üzerinde oluşturulmuştur. Bu sayede, köprü üzerinde her iki köprü ucunda meydana gelebilecek trafik sıkışıklığından dolayı köprü üzerinde meydana gelebilecek en büyük yük değerleri gözönüne alınmış olmaktadır. Köprü her iki şeridinde farklı tip araçların birikmesi olasılığı bulunuyorsa da bu çalışmada maksimum yük değerleri dikkate alınarak en olumsuz durumun incelenmesi amaçlanmıştır. 
Tablo 3. Araç cinsleri ve yükleri

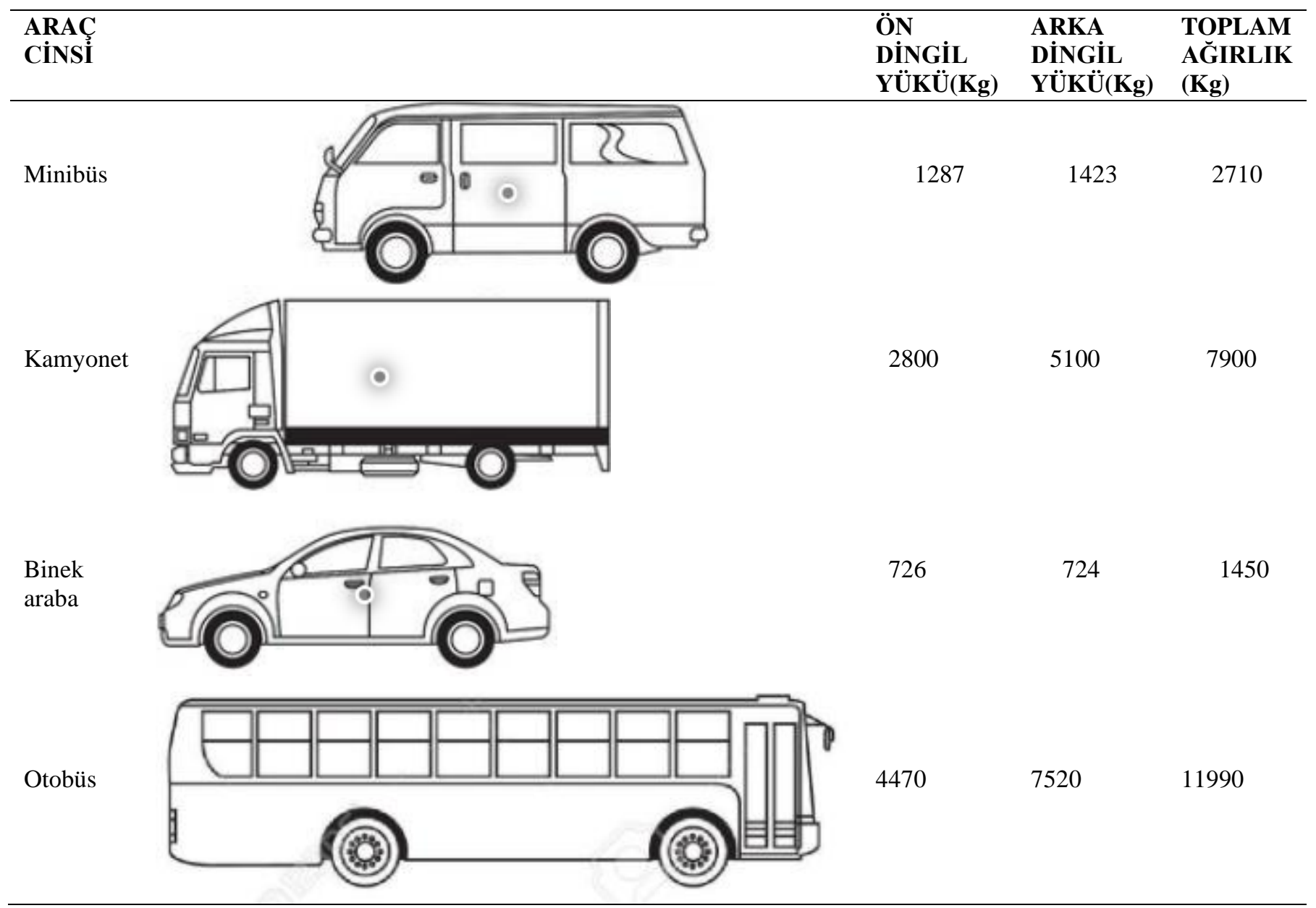

\subsection{Otomobil Yükü Altında NonLineer Statik Analiz}

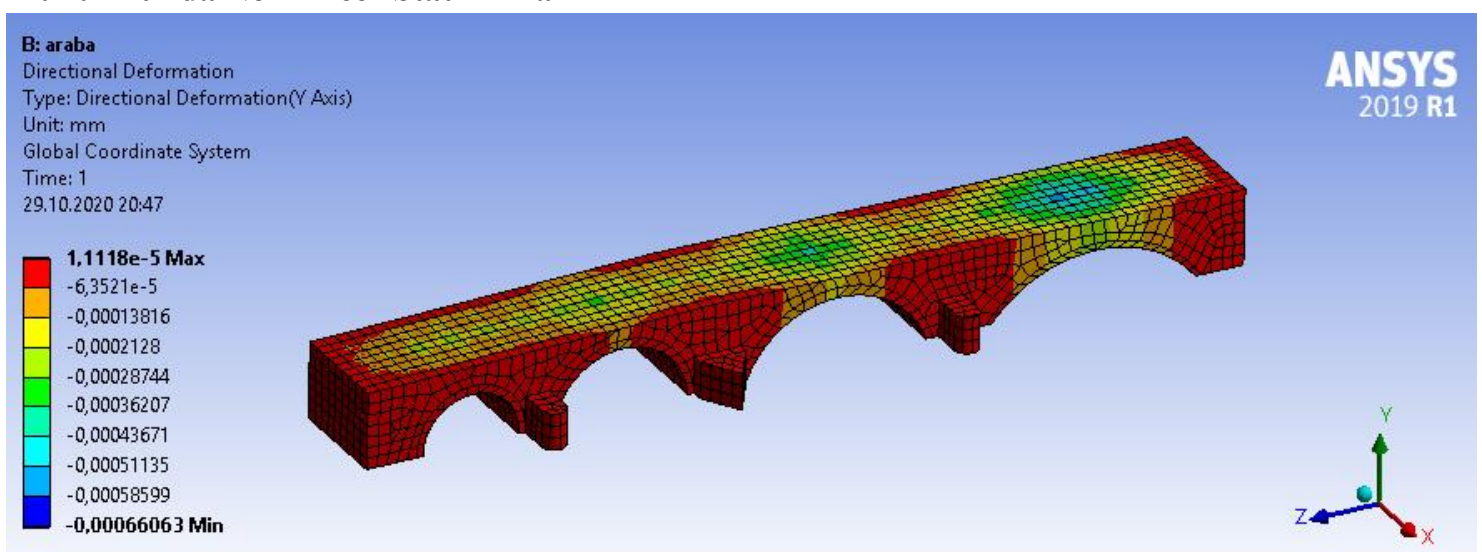

Şekil 5. Otomobil yükü altında elde edilen deformasyon dağılımı

Otomobil yükü altında oluşan deformasyon dağılımı Şekil 5 de görülmektedir. Maksimum deformasyon değeri $0.00066 \mathrm{~mm}$ olarak basık kemer tepe noktasında okunmaktadır. 


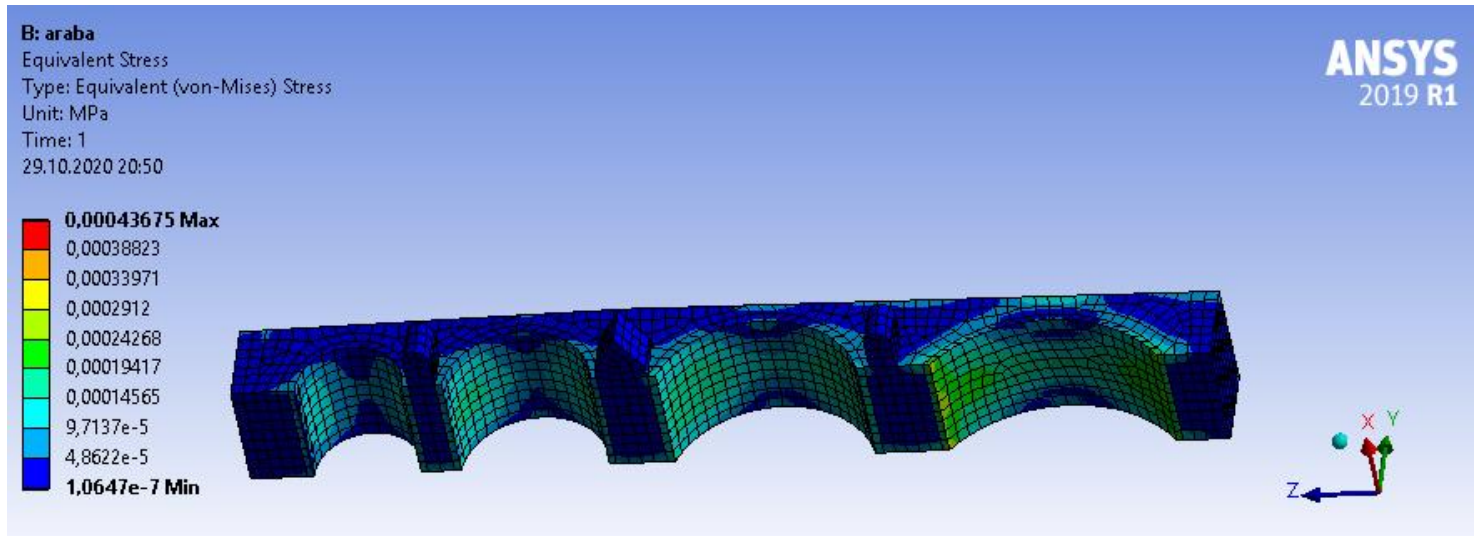

Şekil 6. Otomobil yükü altında elde edilen eşdeğer gerilme dağılımı

Otomobil yükü altında oluşan von Mises gerilme dağılımı Şekil 6 da görülmektedir. Maksimum gerilme değeri 0.000436 MPa olarak basık kemer mesnet noktalarında okunmaktadır.

\subsection{Minibüs Yükü Altında NonLineer Statik Analiz}

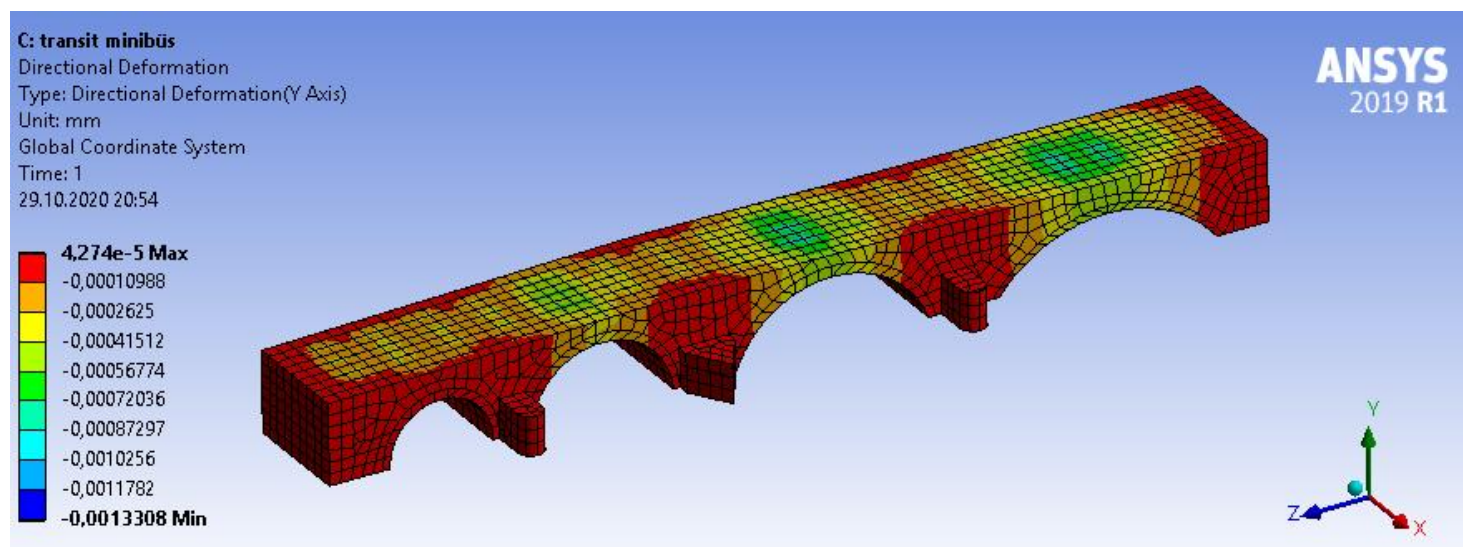

Şekil 7. Minibüs yükü altında elde edilen deformasyon dağılımı

Minibüs yükü altında oluşan deformasyon dağılımı Şekil 7 de görülmektedir. Maksimum deformasyon değeri $0.00133 \mathrm{~mm}$ olarak basık kemer tepe noktasında okunmaktadır. Orta kemer ve diğer küçük kemer tepe noktalarında da deformasyonlar yüksek değerler almaktadırlar.

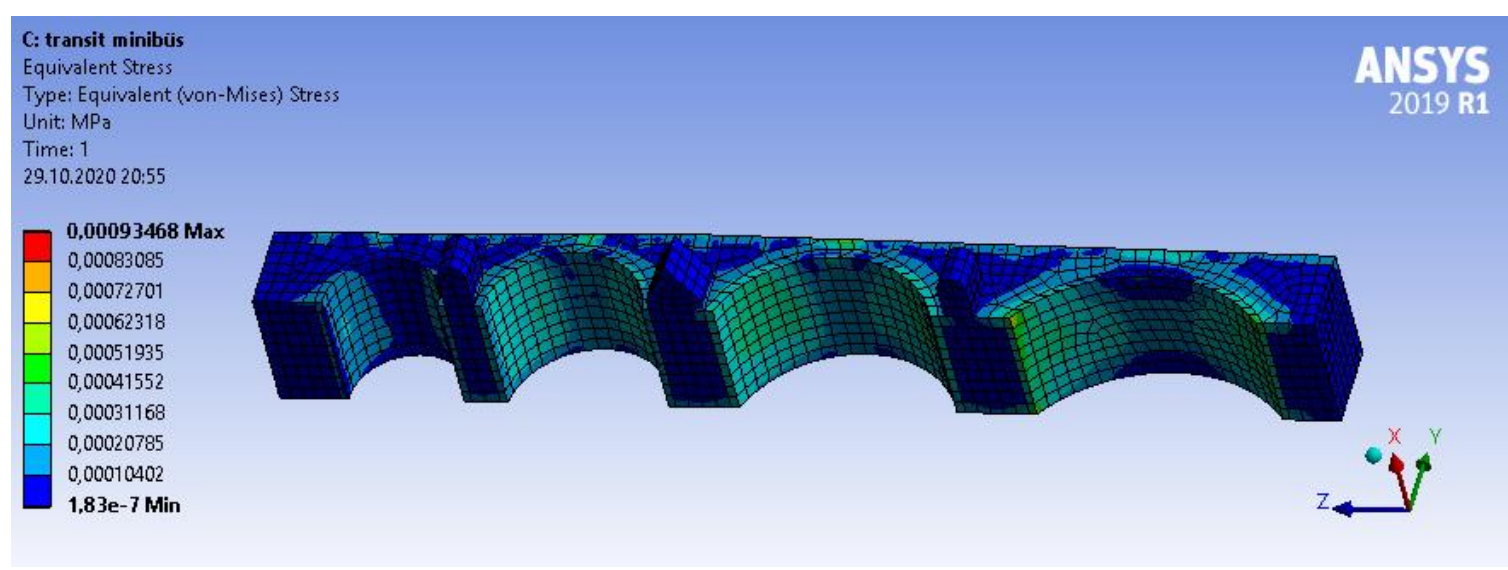

Şekil 8. Minibüs yükü altında elde edilen eşdeğer gerilme dağılımı

Minibüs yükü altında oluşan von Mises gerilme dağılımı Şekil 8 de görülmektedir. Maksimum gerilme değeri 0.000934 MPa olarak basık kemer mesnet noktalarında okunmaktadır. Orta kemer ve diğer küçük kemer tepe noktalarında, kemer üçtebir noktalarında gerilmeler yüksek değerler almaktadırlar. 


\subsection{Kamyonet Yükü Altında NonLineer Statik Analiz}

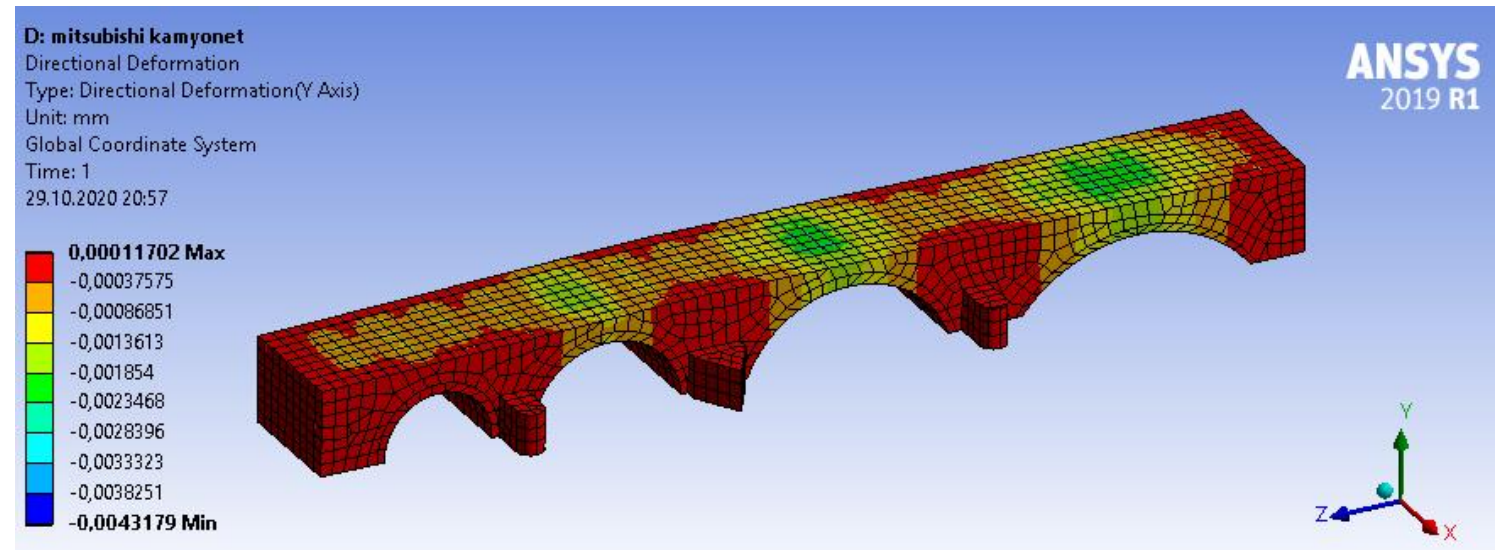

Şekil 9. Kamyonet yükü altında elde edilen deformasyon dağılımı

Kamyonet yükü altında oluşan deformasyon dağılımı Şekil 9 da görülmektedir. Maksimum deformasyon değeri $0.00431 \mathrm{~mm}$ olarak basık kemer tepe noktasında okunmaktadır. Orta kemer ve diğer küçük kemer tepe noktalarında da deformasyonlar yüksek değerler almaktadırlar.

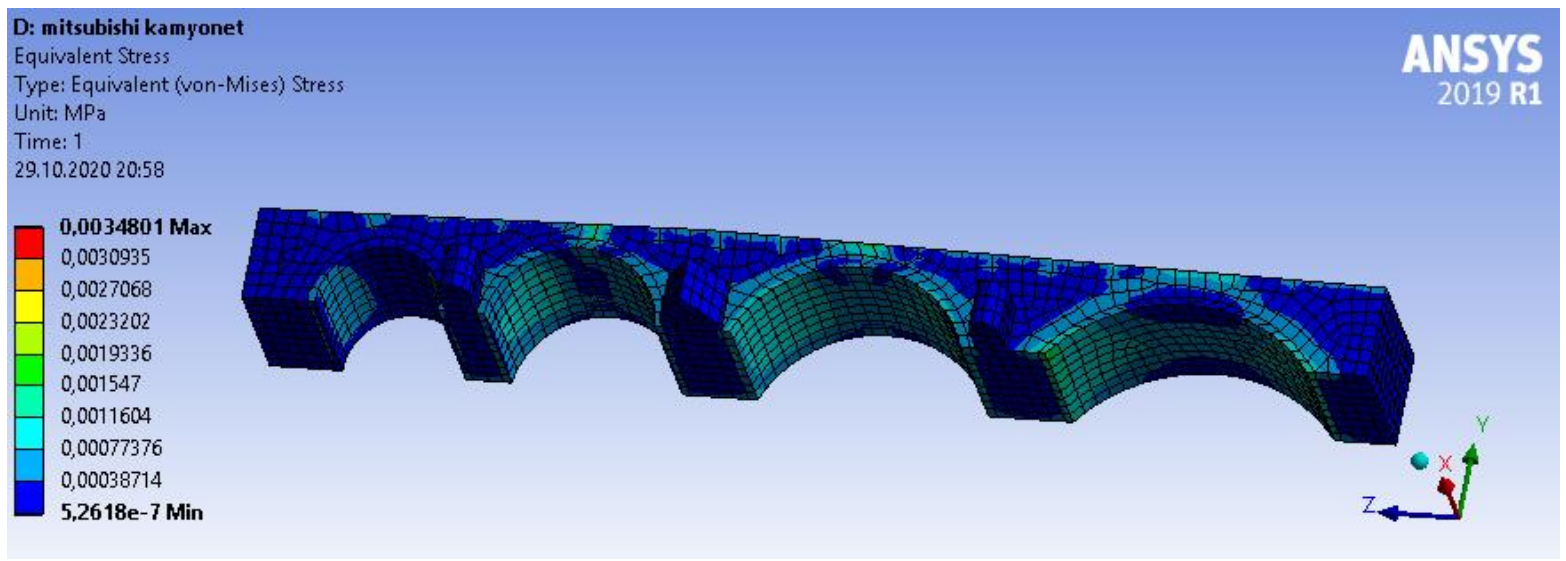

Şekil 10. Kamyonet yükü altında elde edilen eşdeğer gerilme dağılımı

Kamyonet yükü altında oluşan von Mises gerilme dağılımı Şekil 10 da görülmektedir. Maksimum gerilme değeri 0.00348 MPa olarak basık kemer mesnet noktalarında okunmaktadır. Orta kemer ve diğer küçük kemer tepe noktalarında, kemer üçtebir noktalarında gerilmeler yüksek değerler almaktadırlar.

\subsection{Otobüs Yükü Altında NonLineer Statik Analiz}

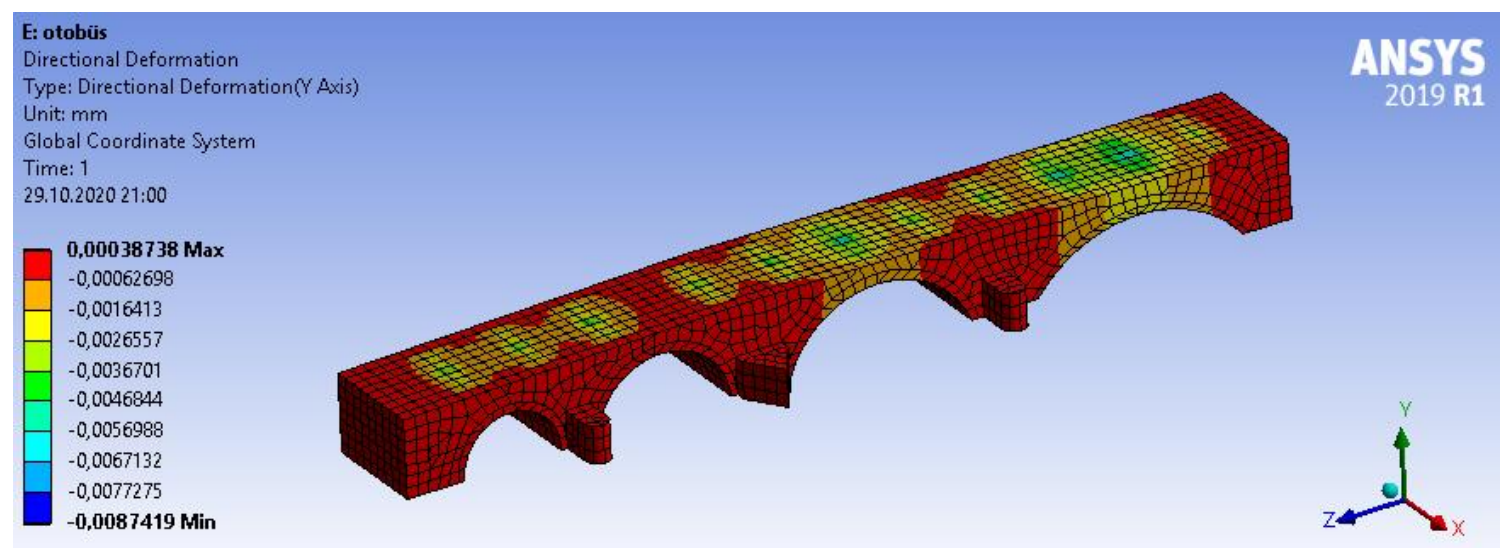

Şekil 11. Otobüs yükü altında elde edilen deformasyon dağılımı 
Otobüs yükü altında oluşan deformasyon dağılımı Şekil 11 de görülmektedir. Maksimum deformasyon değeri $0.00874 \mathrm{~mm}$ olarak basık kemer tepe noktasında okunmaktadır. Orta kemer ve diğer küçük kemer tepe noktalarında da deformasyonlar yüksek değerler almaktadirlar.

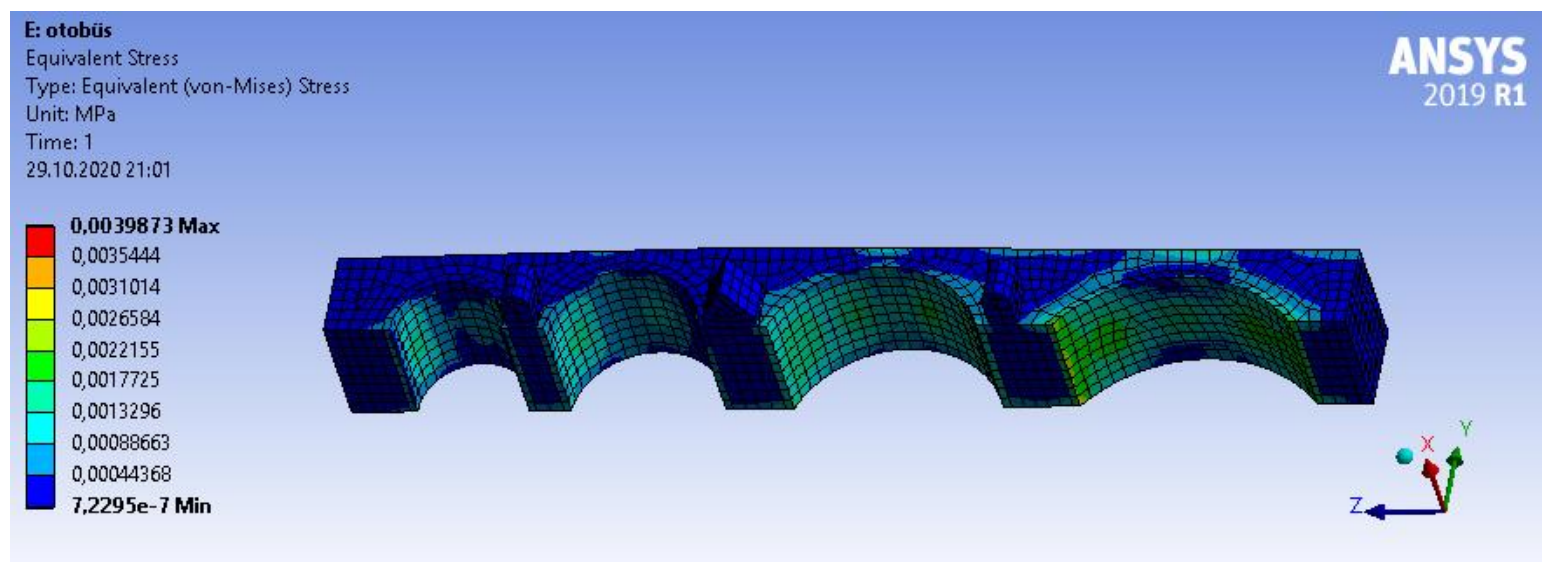

Şekil 12. Otobüs yükü altında elde edilen eşdeğer gerilme dağılımı

Kamyonet yükü altında oluşan von Mises gerilme dağılımı Şekil 12 de görülmektedir. Maksimum gerilme değeri 0.00398 MPa olarak basık kemer mesnet noktalarında okunmaktadır. Orta kemer ve diğer küçük kemerler tepe noktalarında, kemer üçtebir noktalarında gerilmeler yüksek değerler almaktadırlar.

\section{Rijit Blok Analizi}

LimitState:RING yığma kemer köprülerin analizi için kullanılan bir yazılımdır. Yazııım, geniş bir alandaki potansiyel tepki modlarının tanımlanması için matematiksel optmizasyon işlemini ve rijit blok analizi metodunu kullanmaktadır. Program tek ve çok açıklıklı kemer köprülerin nihai taşıma güçlerini hesaplamaktadır. Program kemer yapıyı rijit blokların birleşimi olarak ele almaktadır. Yapı birleşim noktalarında sıfır kalınlık ve çekme gerilmesi dayanımlı olarak düşünülmektedir. Köprü üzerine uygulanan dingil yükünün, kemer üst noktalarından alt noktalarına ve dolgu malzemesinin kemerlere olan etkisi de programda gözönüne alınmakta ve yapı gerçek duruma oldukça yakın bir şekilde analiz edilebilmektedir (https://www.limitstate.com/)

$\mathrm{Bu}$ yazılım kullanarak mevcut köprü üzerine sabit $1 \mathrm{kN}$ luk dingil yükü etkitilmiştir. Yazılım, bu sabit yükün farklı noktalara uygulanarak, köprü yıkılma mekanizmasını gösterebilmesine olanak sağlamaktadır. Yük uygulandıktan sonra, yeterlilik faktörü adı altında program tarafından verilen sayısal değerin dingil yükü ile çarpılması ile, köprü yenilme yük değeri elde edilmektedir. Mevcut köprü için bu analiz gerçekleştirilmiş ve yıkılma mekanizmaları ile yeterlilik faktör değerleri Tablo 4 de verilmiştir.

Tablo 4. Köprü yenilme mekanizmaları ve yeterlilik faktörleri

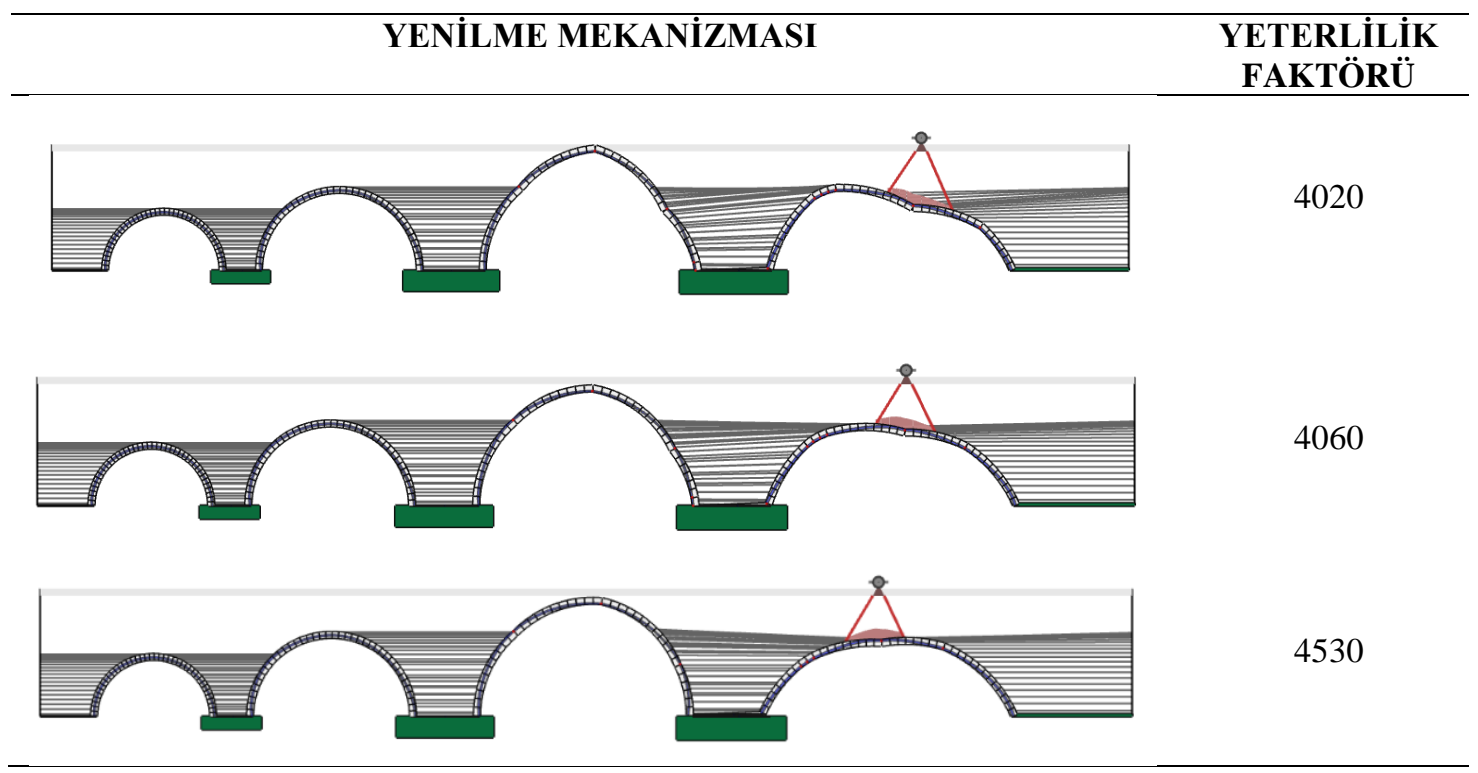


Tablo 4 (devam). Köprü yenilme mekanizmaları ve yeterlilik faktörleri

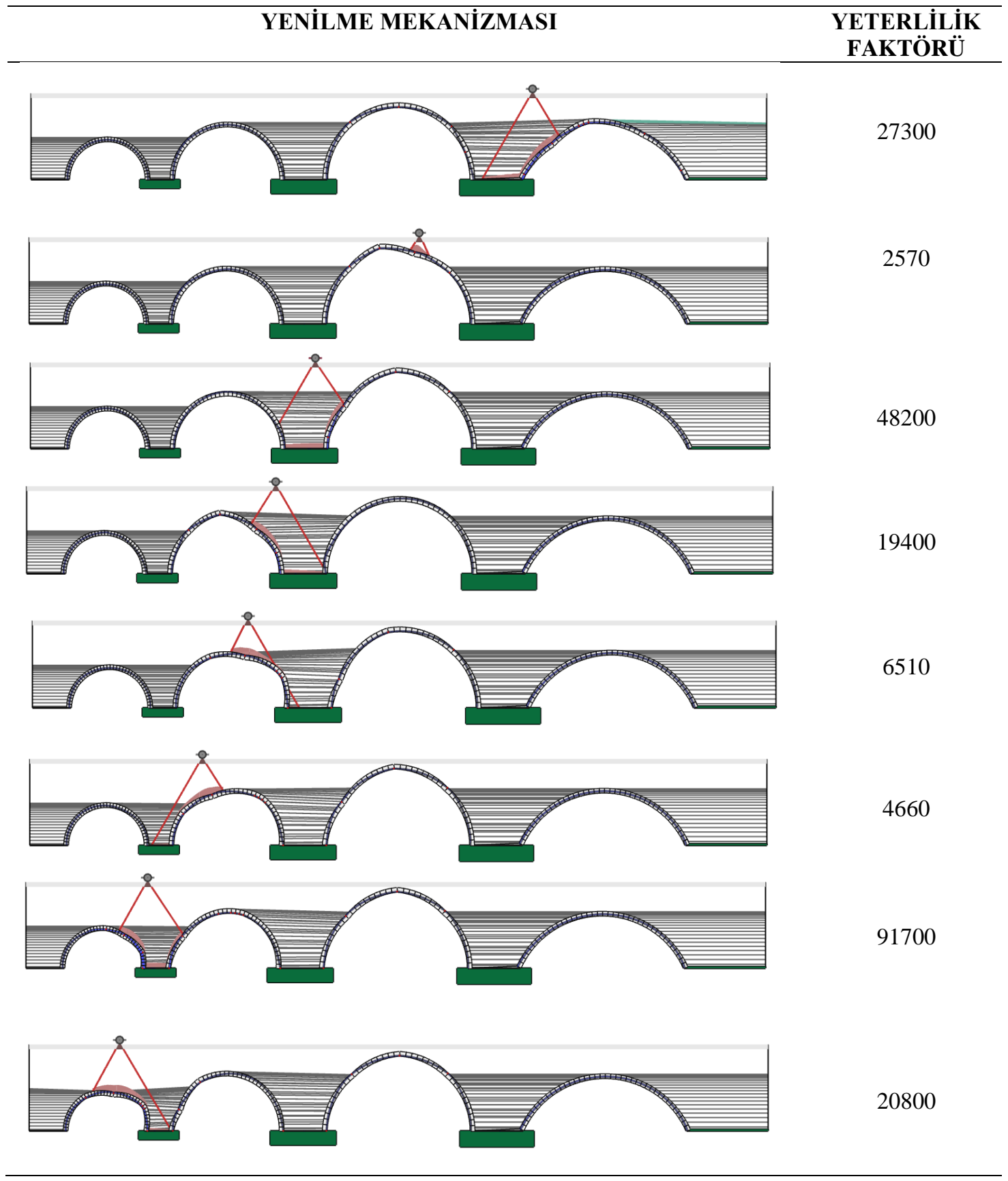

\section{Sonuçlar}

Tarihi eserler bakımından olukça zengin bir yapıya sahip olan Amasya kentinde bulunan Hundi Hatun (Kunç) köprüsü mevcut trafik yükleri altında lineer malzeme özelliği de dikkate alınarak incelenmiştir. Köprü üzerinde her iki şeritin dört farklı araç yükü ile tam olarak dolu olduğu durumlar gözönüne alınmıştır. Bu araçlar; otomobil, minibüs, kamyonet ve otobüstür. Adı geçen bu araç yükleri altında yapılan statik yüklemeler neticesinde şu sonuçlar elde edilmiştir:

- En küçük yük olan otomobil yükü altında, gerilme ve deformasyon değerleri en büyük basıklık oranına sahip olan kemerde ortaya çıkarken, yük değeri arttırıldığında gerilmeler diğer kemerlerde de yüksek değerler almaya başlamaktadır. Fakat en büyük deformasyon değeri, yine en büyük basıklık oranına sahip kemerde ortaya çıkmaktadır.

- Deformasyonlar bütün yükleme tiplerinde, köprü yol güzergahı boyunca ortaya çıkmaktadır. Bu durumunda, zamanla köprü üst yol bölümünde bozulmaların ortaya çıkmasına sebep olacağı tespit edilmektedir.

- Yine tüm yükleme tipleri gözönüne alındığında, gerilmeler kemer alt noktalarından başlayarak üst kısımlara doğru gelişim göstermektedir. Köprüye etkiyen yük değeri yükseldikçe, gerilme değerleri daha büyük bir alana yayılım göstermektedir. 
- Tüm yükleme tiplerinde gerilme değeri emniyetli gerilme değeri olan 0,81 MPa dan, deformasyon değerleri ise $10 \mathrm{~mm}$ 'den (Kaya, 2018) küçüktür. Bu yükleme tipleri altında köprü, gerilme ve deformasyonlar açısından güvendedir.

- Statik yükleme durumlarında köprü güvende olmasına rağmen, uzun süreli tekrarlı yüklemelerde, oluşan çekme gerilmelerinin köprü de bozulmaya yol açabileceği tespit edilmektedir. Dolayısı ile, tüm yığma birimlerin birbirlerine çekme gerilmesini karşılayan demir kenetlerle bağlanmasının gerekliliği ortaya çıkmaktadır.

- Rijit blok analizi neticesinde ise, köprüde plastik mafsalların oluşmasını sağlayacak minimum dingil yükünün 257 ton gibi oldukça yüksek bir değer olduğu tespit edilmiştir. Bu durumun, yükün yüksekliği en fazla olan orta kemer üçtebir noktasında iken oluştuğu tespit edilmektedir. Bu yük değeri sadece bu kemerde yenilme mekanizması oluşturmaktadır.

- Köprüyü yıkılma durumuna getirebilecek ikinci en küçük dingil yükü değeri $402 \mathrm{t}$ olup, en büyük basıklığa sahip kemer üzerine uygulandığında ortaya çıkmaktadır. Fakat burada oluşan yenilme mekanizması bu kemerle sınırlı kalmamakta, bitişik diğer kemerde de plastik mafsal oluşumuna yol açmaktadır. Bu durumda, kemer geometrisinin köprü taşıma gücünde oldukça önemli olduğunu göstermektedir.

- Yine rijit blok analizi neticesinde, dingil yüklerinin kemerler arası bölgelerde çok büyük değerler sahip olduğunda yenilme mekanizması oluşturmasına rağmen, kemer tepe noktaları sağ ve sol kısımlarındaki kemer geometrisi üçte bir bölgesine uygulandıklarında, çok daha kü̧̈ük değerlerle plastik mafsal oluşumuna neden olabilecekleri belirlenmiş olmaktadır.

- Yenilmeye neden olacak dingil yükünün çok yüksek (257 ton) olmasından dolayı, halihazırda köprünün mevcut trafik yükünü statik durumda emniyetle taşıyabileceği görülmektedir.

Çalışmanın, ileride köprü üzerinde yapılabilecek restorasyon ve renovasyon faaliyetlerine yol gösterici olması hedeflenmektedir.

\section{Referanslar}

Altaş, G.K., Özgünler, S.A. ve Güldal, E. (2012). İstanbul'daki Roma Dönemi Saray Yapılarındaki Horasan Harçlarının İncelenmesi. Vakıf Restorasyon Yıllığı. Sayı:4. 42-49.

ANSYS (2019). Finite Element Software. USA.

Ataei, S., Miri, A., \& Jahangiri, M. (2017). Assessment of load carrying capacity enhancement of an open spandrel masonry arch bridge by dynamic load testing. International Journal of Architectural Heritage, 11(8), 1086-1100.

https://doi.org/10.1080/15583058.2017.1317882

Augusthus-Nelson, L., \& Swift, G. (2020). Experimental investigation of the residual behaviour of damaged masonry arch structures. Structures, 27(March), 2500-2512. https://doi.org/10.1016/j.istruc.2020.08.008

Conde, B., Díaz-Vilariño, L., Lagüela, S., \& Arias, P. (2016). Structural analysis of Monforte de Lemos masonry arch bridge considering the influence of the geometry of the arches and fill material on the collapse load estimation. Construction and Building Materials, 120, 630-642. https://doi.org/10.1016/j.conbuildmat.2016.05.107

Çakır, F., Şeker, B. Ş. (2015). Structural performance of renovated masonry low bridge in Amasya, Turkey. Earthquakes and Structures, Vol 8, No:6, 1387-1406.

Çulpan, C. (2002). Türk Taş Köprüleri, Ortaçağdan Osmanlı Devri Sonuna Kadar. Türk Tarih Kurumu Basımevi. Ankara.

Hokelekli, E., \& Yilmaz, B. N. (2019). Effect of cohesive contact of backfill with arch and spandrel walls of a historical masonry arch bridge on seismic response. Periodica Polytechnica Civil Engineering, 63(3), 926-937. https://doi.org/10.3311/PPci.14198

http://cografyaharita.com/haritalarim/41_amasya_ili_haritasi.png

https://en.wikipedia.org/wiki/Mohr\%E2\%80\%93Coulomb_theory

https://www.google.com/maps/@40.6579007,35.8350253,17.79z?hl=tr

https://www.limitstate.com/

Kamiński, T. (2018). The ultimate limit state vs. Limit analysis of masonry arch bridges. Maintenance, Safety, Risk, Management and Life-Cycle Performance of Bridges - Proceedings of the 9th International Conference on Bridge Maintenance, Safety and Management, IABMAS 2018, (July 2018), 2687-2694.

Karaton, M., Aksoy, H. S., Sayın, E., \& Calayır, Y. (2017). Nonlinear seismic performance of a 12th century historical masonry 
bridge under different earthquake levels. Engineering Failure Analysis, 79(December 2016), 408-421. https://doi.org/10.1016/j.engfailanal.2017.05.017

Karaton, M., Aksoy, H.S. and Sayın E. (2017). Nonlinear seismic performance of a 12th century historical masonry bridge under different earthquake levels. Engineering Failure Analysis. 79. 408-421.

Kaya, M. (2018). Aksaray Debbağlar Köprüsü: Günümüz Trafik Yükleri Altında Dinamik Analizi. Yüksek Lisans Tezi. Süleyman Demirel Üniversitesi. Fen Bilimleri Enstitüsü. Isparta.

Kindij, A., Mandic Ivankovic, A., \& Vasilj, M. (2013). Assessment of Masonry Arch Bridge With Concrete Deck. 7th International Conference on Arch Bridges (ARCH’13), (May), 723-730.

Kolla, Abhinav, Ravi Naga Sai Kurapati, Sree Satya Venkat Meka, Venkata Sai Madhu Dinesh Vitakula, and Venkata Dilip Kumar Pasupuleti. (2021). Health Assessment and Modal Analysis of Historical Masonry Arch Bridge. Springer International Publishing. https://doi.org/10.1007/978-3-030-64594-6_88.

Meriç C., Ç., \& Bağbancı, M. B. (2019). The Investigation of Construction Techniques and Material Usage of Historical Stone Bridges in Anatolia and Balkans. In International Refereed Journal of Design and Architecture (Vol. 17).

https://doi.org/10.17365/tmd.2019.2.4

Nobile, Lucio, and Veronica Bartolomeo. (2015). Structural Analysis of Historical Masonry Arches: State-of-the-Art and Recent Developments. International Journal of Mathematical Models and Methods in Applied Sciences 9: 338-44.

Onat O, \& Yön B. (2018). Adopted Material Properties of Historical Masonry Structures for Finite Element Models: Mosques and Bridges. Turkish Journal of Science \& Technology Volume 13(1), 69-75.

Özmen, A., and Sayın E. (2018). Seismic Assessment of a Historical Masonry Arch Bridge. Journal of Structural Engineering \& Applied Mechanics 1 (2): 95-104. https://doi.org/10.31462/jseam.2018.01095104.

Paeglitis, A., Paeglitis, A., Vitina, I., \& Igaune, S. (2013). Istorinio mūrinio arkinio tilto tyrimas ir atnaujinimas. Baltic Journal of Road and Bridge Engineering, 8(1), 32-39. https://doi.org/10.3846/bjrbe.2013.05

Pelà, L., Aprile, A., \& Benedetti, A. (2009). Seismic assessment of masonry arch bridges. Engineering Structures, 31(8), $1777-1788$. https://doi.org/10.1016/j.engstruct.2009.02.012

Pepi, C., Gioffrè, M., Comanducci, G., Cavalagli, N., Bonaca, A., \& Ubertini, F. (2017). Dynamic characterization of a severely damaged historic masonry bridge. Procedia Engineering, 199(December), 3398-3403. https://doi.org/10.1016/j.proeng.2017.09.579

Pouraminian, M., Pourbakhshian, S., Noroozinejad Farsangi, E., Berenji, S., Borujeni, S. K., Moosavi Asl, M., \& Mohammad Hosseini, M. (2020). Reliability-Based Safety Evaluation of the BISTOON Historic Masonry Arch Bridge. Civil and Environmental Engineering Reports, 30(1), 87-110. https://doi.org/10.2478/ceer-2020-0008

Rahman, M. E., \& Fanning, P. J. (2010). An examination of backing effects on ratings for masonry arch bridges. World Academy of Science, Engineering and Technology, 72(September), 314-316. https://doi.org/10.5281/zenodo.1063128

Rodrigo, B. G., Olària, S. R. i, Fernández-Ordoñez, D., \& Gómez, J. M. C. S. (2015). Rehabilitation of historic masonry bridges: Lessons learned from a medieval bridge in northeast Spain. Revista de La Construccion, 14(2), 9-13. https://doi.org/10.4067/s0718$915 \times 2015000200001$

Rodrigues, N., Ramos, A., \& Branco, F. (2008). Rehabilitation of Historical Masonry Bridges. 1st International Conference Construction Heritage in Coastal and Marine Environments -- Damage, Diagnostic, Maintenance and Rehabilitation, (January 2008), 1-10. https://doi.org/10.13140/2.1.3993.6007

Tiberti, S. and Milani, G. (2018). Historic City Centers After Destructive Seismic Events, The Case of Finale Emilia During the 2012 Emilia-Romagna Earthquake: Advanced Numerical Modelling on Four Case Studies. Open Civ. Eng. Journal. Vol. 11, No. 1. pp. 1059-1078.

Tubaldi, E., Minga, E., Macorini, L., \& Izzuddin, B. A. (2020). Mesoscale analysis of multi-span masonry arch bridges. Engineering Structures, 225(November 2019), 111137. https://doi.org/10.1016/j.engstruct.2020.111137

Türkiye Bina Deprem Yönetmeliği. (2019). Afet ve Acil Durum Yönetimi Başkanlığı. 